Jurnal Inkofar * Volume 1 No. 2, Desember 2017 * ISSN: 2615-3645 (Print) / 2581-2920 (Online)

Tersedia secara online di: http://www.politeknikmeta.ac.id/meta/ojs/

\title{
RANCANG BANGUN SISTEM INFORMASI AKADEMIK POLITEKNIK META INDUSTRI
}

\author{
Fritz Gamaliel \\ Program Studi Teknik Komputer, Politeknik META Industri Cikarang, Bekasi, Indonesia \\ Email: fritzgamaliel@politeknikmeta.ac.id
}

\begin{abstract}
Politeknik Meta Industri is one of the higher education institution. Currently, Politeknik Meta Industri has SIAKAD (academic information system), but operators are afraid to use. In this paper, we designing SIAKAD for Politeknik Meta Industri. The SIAKAD was implemented in PHP and MySQL. The proposed SIAKAD was acceptable by all stakeholders (student, staff, and institution). Operators don't afraid to use it.
\end{abstract}

Keywords: academic information system, $P H P, M y S Q L$

\begin{abstract}
ABSTRAK
Politeknik Meta Industri adalah salah satu lembaga pendidikan tinggi diploma tiga. Saat ini sudah ada SIAKAD (Sistem Informasi Akademik) di Politeknik Meta Industri, tetapi yang menjadi masalah adalah operator takut menggunakannya. Pada makalah ini, kami merancang SIAKAD untuk kemudian diterapkan pada Politeknik Meta Industri. SIAKAD yang dirancang diimplementasikan ke dalam bahasa pemograman PHP dan basis data MySQL. SIAKAD yang dirancang dapat diterima oleh semua yang kepentingan (mahasiswa, staff, dan yayasan). Selain itu, operator tidak takut menggunakannya.
\end{abstract}

Kata Kunci: sistem informasi akademik, PHP, MySQL

\section{PENDAHULUAN}

Pesat perkembangan teknologi informasi dan komunikasi, memungkinkan perkembangan layanan informasi yang lebih baik dalam suatu institusi pendidikan. Di lingkungan Politeknik, pemanfaatan teknologi informasi dan komunikasi dapat diwujudkan dalam suatu sistem yang disebut dengan Sistem Informasi Akademik (SIAKAD). SIAKAD bertujuan untuk mendukung penyelenggaraan pendidikan, sehingga Politeknik dapat menyediakan layanan informasi yang lebih baik kepada mahasiswanya, baik di dalam maupun di luar sekolah tersebut melalui internet.

Perguruan tinggi memiliki kewajiban untuk melaporkan akvitas akademik tiap semester melalui aplikasi Feeder, dimana nantinya laporan tersebut akan diposting oleh dikti di laman Pangkalan Data Perguruan Tinggi (PDPT). Saat ini sudah ada SIAKAD di Politeknik Meta Industri, tetapi yang menjadi masalah adalah operator takut menggunakan kembali SIAKAD tersebut sebab sebelumnya operator melihat ketidakbenaran pada hasil olah data oleh SIAKAD tersebut. Jika data yang diteruskan dari SIAKAD ke aplikasi Feeder salah, maka yang diposting oleh Dikti dari aplikasi Feeder ke PDPT pun juga akan salah. Hal ini mengakibatkan operator musti mengajukan surat permohonan kepada Dikti untuk memperbaiki data yang salah tersebut.

Berdasarkan uraian masalah diatas maka hal yang perlu diperhatikan dalam perancangan sistem informasi akademik adalah sinkronisasi antara laporan akademik perguruan tinggi dengan aplikasi Feeder sehingga perlu di buat sebuah rancang bangun sistem informasi akademik yang selaras dengan aplikasi Feeder. Penelitian ini membahas tentang pendataan kegiatan akademik dengan mengacu kepada aplikasi Feeder yang fokuskan pada interaksi yang terjadi antara pengguna dan sistem, proses bisnis, serta rancangan database.

Penelitian ini bertujuan untuk membuat rancang bangun sistem informasi akademik untuk kemudian diterapkan pada Politeknik Meta Industri. Dengan adanya sistem informasi akademik yang penulis buat ini diharapkan dapat menghilangkan ketakutan operator dalam menggunakan SIAKAD dan tidak terjadi hambatan dan kendala dalam penerusan data dari SIAKAD ke aplikasi Feeder. 


\section{METODE PENELITIAN}

\subsection{Metode Pengembangan Perangkat Lunak}

Pendekatan yang kami lakukan dalam membangun suatu sistem informasi akademik ini menggunakan metode Waterfall [Shalahuddin, 2014] dimana tahapan pengembangannya dimulai dari:

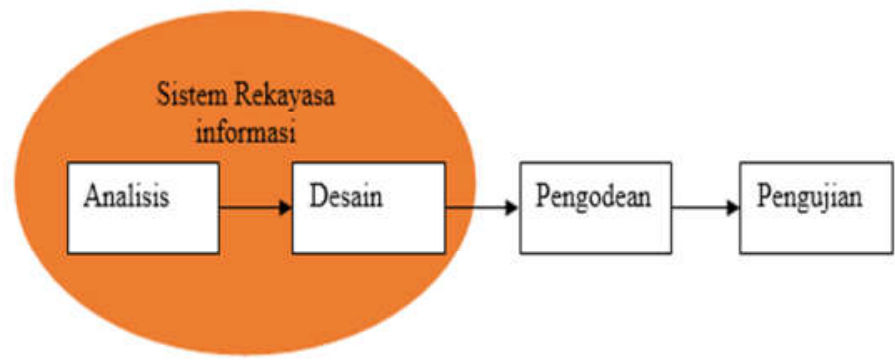

Gambar 1. Ilustrasi Model Waterfall

Sumber: Sukamto dan Shalahuddin . M (2014)

1. Analisis kebutuhan perangkat lunak

Pada tahapan ini penulis mengumpulkan kebutuhan secara intensif dengan cara meninjau langsung dengan melihat berbagi referensi - referensi sistem informasi perpustakaan yang telah ada untuk menspesifikasikan kebutuhan perangkat lunak yang di butuhkan oleh petugas ataupun siswa dalam kata lain user agar dapat digunakan dengan baik.

2. Desain

Pada tahapan desain penulis menfokuskan pada empat atribut, yaitu struktur data, representasi antarmuka, arsitektur perangkat lunak, dan prosedur pengodean. Maka pada tahapa ini penulis menyediakan beberapa desain web yang responsif dengan tujuan dapat dibuka dari berbagai device baik yang memiliki layar besar ataupun kecil. Serta membuat desain yang memudahkan user saat menggunakan sistem informasi tersebut.

3. Pembuatan kode program

Setelah melewati tahapan desain selanjutnya penulis membuat kode program dengan mengacu pada desain sehingga terciptalah kesesuaian antara desain dengan kode program. Hasil dari tahapan ini adalah program komputer sesuai dengan desain yang telah dibuat pada tahapan desain.

4. Pengujian

Selanjutnya di tahapan penguji ini penulis memastikan bahwasannya semua bagian dari sistem secara mendetail untuk meminimalisir segala bentuk kesalahan (error) pada sistem serta memastikan hasil akhir berupa output dari sistem sesuai dengan yang diharapkan.

5. Pendukung (support) atau pemeliharaan (maintenance)

Dengan adanya tahapan ini penulis dapat mengetahui segala kesalahan yang tidak terdeteksi saat tahapan pengujian, sehingga pada tahapan pendukung atau pemeliharaan ini diizinkan untuk mengulangi proses dari tahapan - tahapan sebelumnya namun tidak membuat sistem yang baru.

\subsection{Teknik pengumpulan Data}

Teknik pengumpulan data yang digunakan oleh penulis dalam melakukan pengumpulan data untuk pembuatan penelitian ini adalah:

1. Pengamatan (Observasi)

Penulis melakukan pengamatan secara langsung terhadap kegiatan yang ada di bagian akademik Politeknik Meta Industri baik saat penjadwalan mata kuliah, perkuliahan, penilaian, dan pembayaran uang kuliah. Hasil dari pengamatan tersebut langsung dicatat oleh penulis dan dari kegiatan observasi dapat diketahui bagaimana sistem informasi akademik akan dibuat.

2. Wawancara (Interview)

Pada metode ini penulis memperoleh informasi dengan melakukan tanya jawab kepada mahasiswa yang berada di Politeknik Meta Industri mengenai beberapa hal seperti KRS, KHS, dan Transkrip. Kemudian melakukan tanya jawab kepada petugas akademik mengenai 
bagaimana proses administrasi - administrasi yang terjadi di bagian akademik seperti penjadwalan kuliah, penginputan data nilai, dan pembuatan KHS.

3. Studi Pustaka

Penulis melakukan metode ini untuk memenuhi informasi bagaimana sistem informasi akademik dibuat, sehingga berusaha mendapatkan data dengan cara melihat, membaca, serta mengembangkan informasi yang berkaitan dengan masalah yang dibicarakan sebagai referensi dari berbagai buku cetak, ebook, maupun website E-library yang telah dibuat untuk penunjang penelitian ini.

\section{HASIL DAN PEMBAHASAN}

3.1 Implementasi Antar Muka

Dalam tahap ini penulis akan menjelaskan tentang implementasi antarmuka halaman aplikasi sistem informasi akademik berbasis web pada Politeknik Meta Industri.

1. Implementasi Antar Muka Halaman Login

Halaman ini digunakan untuk masuk ke dalam sistem.

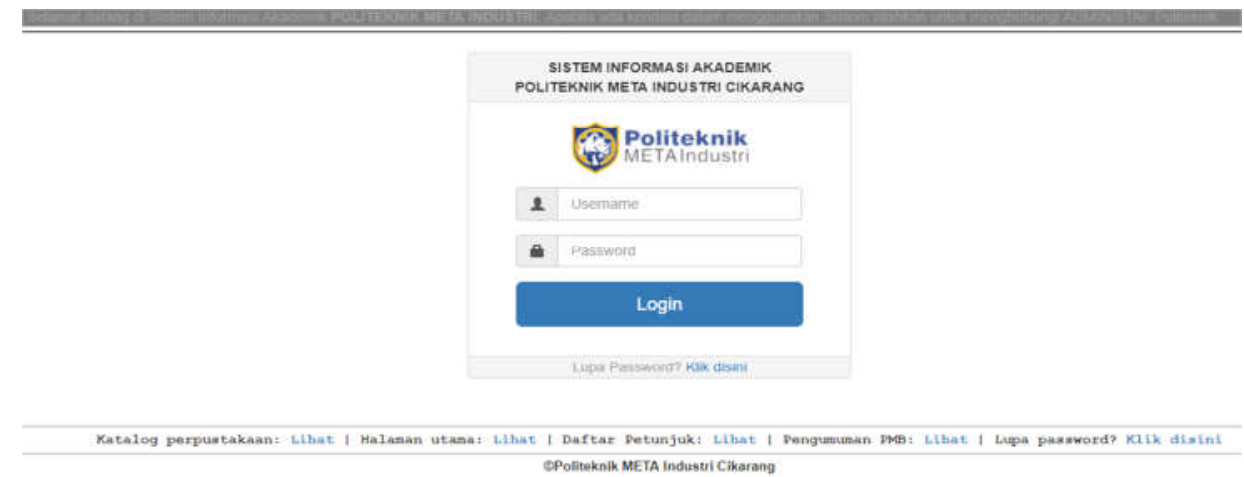

Gambar 2. Rancangan Antar Muka Halaman Login

Sumber: Hasil Penelitian

2. Implementasi Antar Muka Halaman Penjadwalan

Halaman ini digunakan untuk menginput data jadwal kuliah ke dalam sistem.

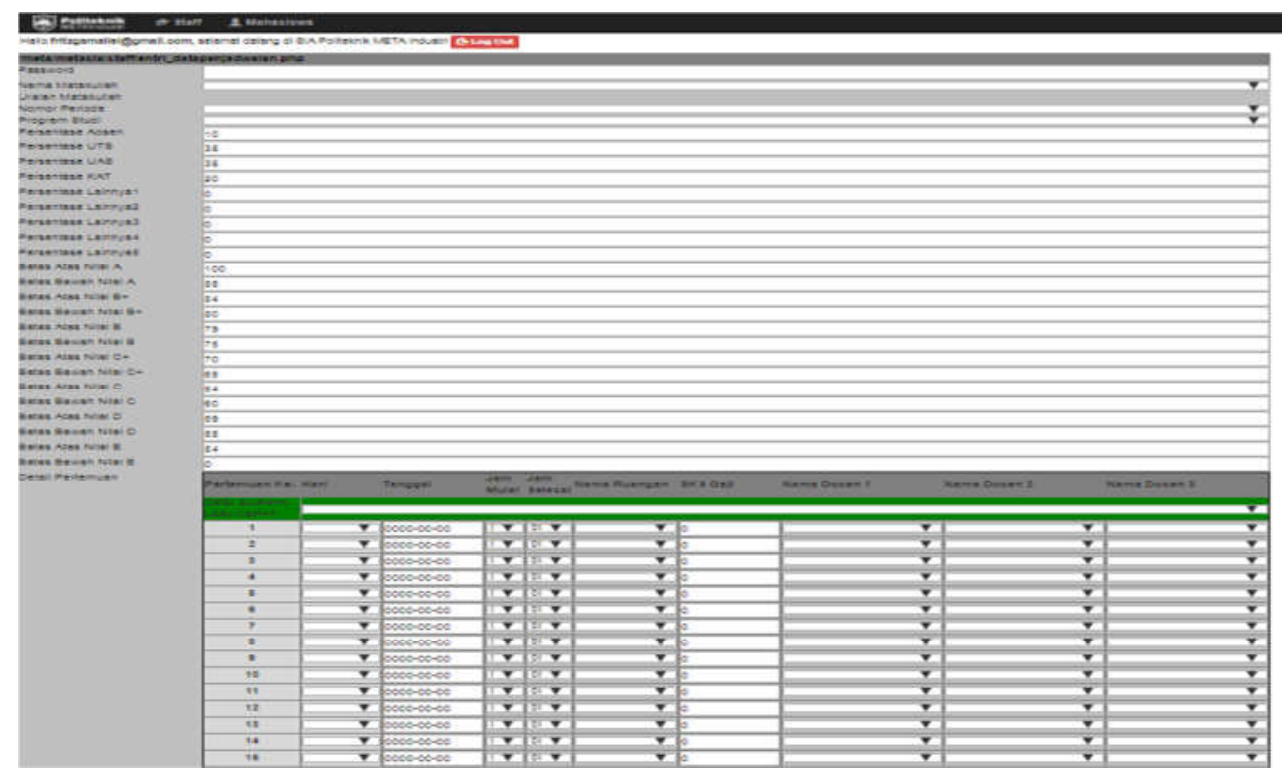

Gambar 3. Rancangan Antar Muka Halaman Penjadwalan

Sumber: Hasil Penelitian 


\subsection{Rancangan Basis Data}

Perancangan basis data menghasilkan pemetaan tabel-tabel dan atribut-atribut serta adanya relasi antar entitas yang digambarkan menggunakan Logical Relationship Diagram (LRS).

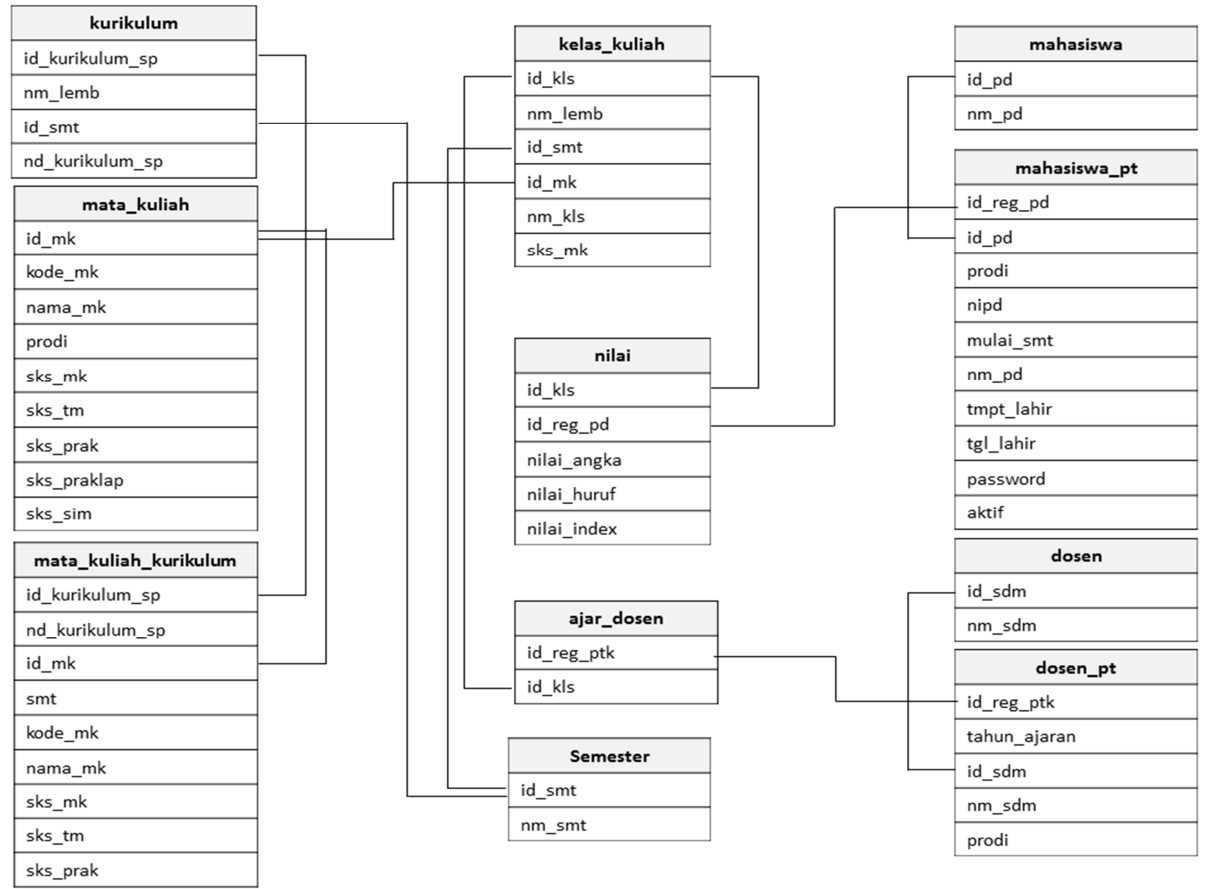

\section{Gambar 4. Logical Relational Structure} Sumber: Hasil Penelitian

\subsection{Rancangan Struktur Navigasi}

Adapun struktur navigasi dari peracangan sistem informasi akademik berbasis web pada Politeknik Meta Industri ini menggunakan struktur navigasi komposit.

1. Struktur Navigasi Halaman Beranda Admin

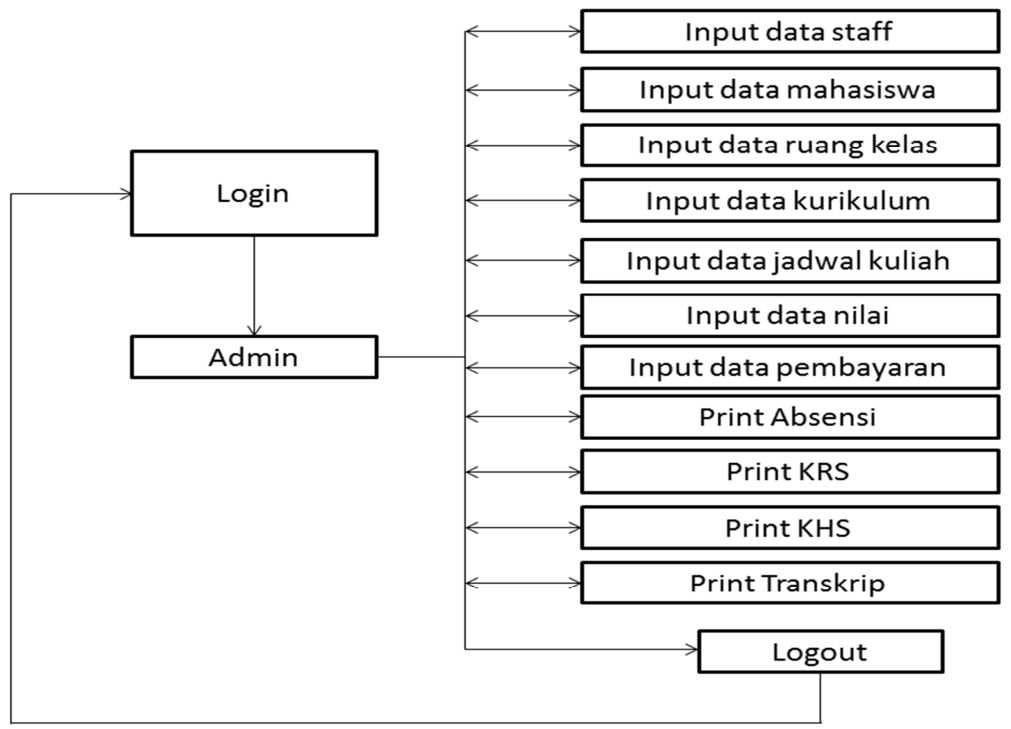

Gambar 5. Struktur Navigasi Halaman Beranda Admin

Sumber: Hasil Penelitian 
Jurnal Inkofar * Volume 1 No. 2, Desember 2017 * ISSN: 2615-3645 (Print) / 2581-2920 (Online)

Tersedia secara online di: http://www.politeknikmeta.ac.id/meta/ojs/

2. Struktur Navigasi Halaman Beranda Mahasiswa

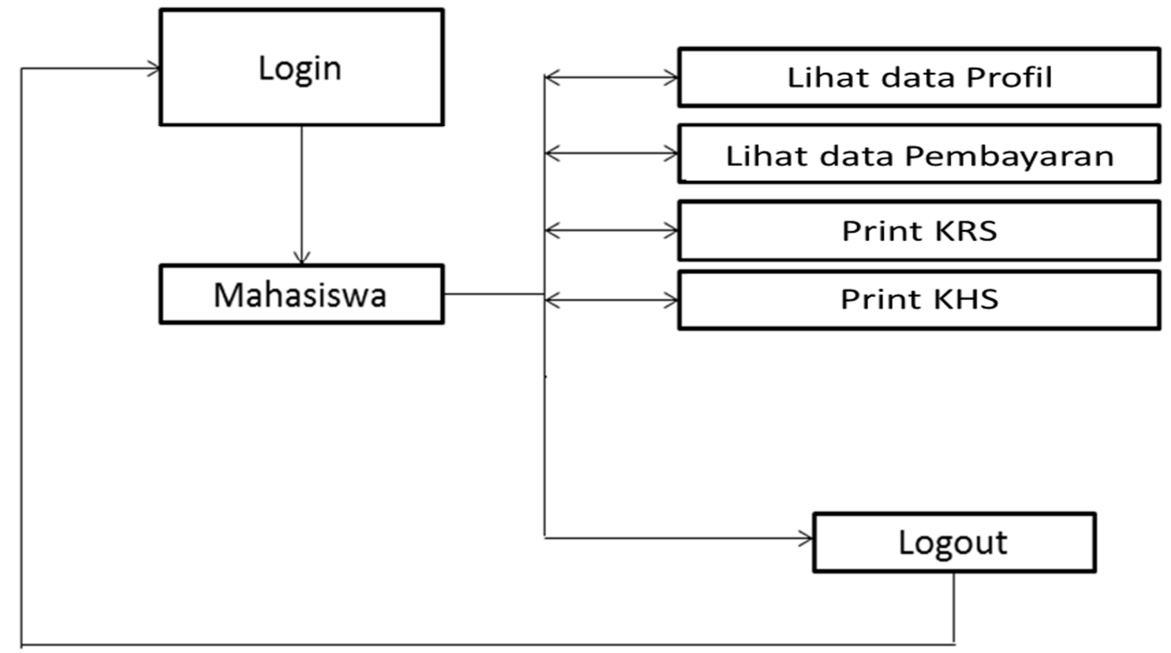

Gambar 6. Struktur Navigasi Halaman Beranda Mahasiswa

Sumber: Hasil Penelitian

\subsection{Pengujian Unit}

Tabel 1.Pengujian Black Box Testing Login

\begin{tabular}{|c|c|c|c|c|c|}
\hline No. & $\begin{array}{l}\text { Skenario } \\
\text { Pengujian }\end{array}$ & Test Case & $\begin{array}{l}\text { Hasil yang } \\
\text { diharapkan }\end{array}$ & $\begin{array}{l}\text { Hasil } \\
\text { Pengujian }\end{array}$ & Kesimpulan \\
\hline 1 & $\begin{array}{l}\text { Input } \\
\text { Username } \\
\text { dan } \\
\text { Password } \\
\text { yang } \\
\text { teregistrasi } \\
\text { di database }\end{array}$ & $\begin{array}{l}\text { Username: } \\
\text { fritzgamaliel } \\
\text { Password: } \\
12345\end{array}$ & $\begin{array}{l}\text { Sistem akan } \\
\text { menerima dan } \\
\text { menampilkan } \\
\text { halaman utama. }\end{array}$ & $\begin{array}{l}\text { Sesuai } \\
\text { Harapan }\end{array}$ & Valid \\
\hline 2 & $\begin{array}{l}\text { Input } \\
\text { Username } \\
\text { dan } \\
\text { Password } \\
\text { yang tidak } \\
\text { teregistrasi } \\
\text { di database }\end{array}$ & $\begin{array}{l}\text { Username: } \\
\text { abcdef } \\
\text { Password: } \\
\text { (kosong) }\end{array}$ & $\begin{array}{l}\text { Sistem akan } \\
\text { menolak dan } \\
\text { menampilkan } \\
\text { pesan "login } \\
\text { gagal" }\end{array}$ & $\begin{array}{l}\text { Sesuai } \\
\text { Harapan }\end{array}$ & Valid \\
\hline
\end{tabular}

\section{KESIMPULAN}

Dari hasil pembahasan masalah yang telah diuraikan dapat disimpulkan sebagai berikut dengan adanya Sistem Informasi Akademik yang baru berbasis web pada Politeknik Meta Industri mampu menghilangkan kekhawatiran operator dalam menggunakan aplikasi SIAKAD dan juga dapat diterima oleh mahasiswa, staff, yayasan, dan dikti.

\section{DAFTAR PUSTAKA}

Sommerville, I. 2011. "Software Engineering: $9^{\text {th }}$ edition", Pearson Education. http://www.kopertis12.or.id/2015/02/26/panduan-aplikasi-pddikti-feeder-2015.html https://developer.bca.co.id/ 